\title{
Collaborative Climate and Knowledge Sharing among ESP Teachers: A Mixed Method Study
}

\author{
Majid Farahian, Farshad Parhamnia \\ Islamic Azad University, Kermanshah Branch
}

\begin{abstract}
Correspondence concerning this article should be addressed to Majid Farahian, Department of ELT, Kermanshah Branch, Islamic Azad University, Kermanshah, Iran. E-mail: majid.farahian@gmail.com
\end{abstract}

\begin{abstract}
Research on teacher collaboration emphasizes the key role of collaborative culture for teachers' functioning; however, there is little empirical evidence to investigate its relationship with knowledge sharing among university ESP teachers. In the present study, the relationship between EFL teachers' collaborative climate and knowledge sharing was sought. The data were collected through two surveys of 328 Iranian ESP teachers. A Pearson correlation was carried out to investigate the relationship between the two variables of the study. A multiple regression analysis was also run to examine if ESP teachers' collaborative climate predicts their knowledge sharing. A follow-up interview with 13 ESP teachers was conducted to consolidate the findings and explore the contribution of teachers' collaborative climate to their knowledge sharing. The Pearson correlation coefficient test demonstrated a significant positive correlation for four measures (organizational culture, the head of department, teachers' attitude, workgroup support), and the collaborative climate. The results of the multiple regression also indicated that four subscales of collaborative climate were the predictors of ESP teachers' attitude towards knowledge sharing. Analysis of the interview data, on the other hand, indicated how teachers' collaborative climate contributes to their knowledge sharing through one of the four main sources, namely helpful atmosphere, encouragement received from the heads of departments, the expectation of reward, and work group support. In line with these findings, several practical recommendations were offered.
\end{abstract}

Keywords: collaborative climate, knowledge sharing, ESP teachers

\section{Introduction}

Learning a foreign language, especially English, has become increasingly important in all fields of study. This feature is more evident in ESP, where there is a growing demand in ESP courses for mastering English language skills (Rajprasit, Pratoomrat, \& Wang, 2015). In this regard, students should learn English because of their future careers and the need to identify, access, select, and use a wide range of information in English that must be regularly updated. However, unfortunately, many of these students have not been able to acquire sufficient mastery in English.

In Iran, all students with different majors should pass a three-credit course called General English, after which a two-or-more-credit ESP course is required. The three-credit course places a great emphasis on comprehension skills and general vocabulary development. Likewise, it is very important for ESP courses to enable students to read and understand English for special purposes. The goal of ESP courses is to prepare students to read common texts and words related to the topic. In general, this course is based on two assumptions: a) matching the content of the course with the field of the students and b) limited improvement of comprehension and reading skills as well as grammar and vocabulary (Ghonsooly \& Pishgadam, 2011). However, apart from the importance and necessity of these courses, the role of ESP teachers' characteristics and their ability to teach ESP play a pivotal role.

One topic that has received less attention in education is knowledge management. Knowledge management is defined as «the process of collecting, managing and sharing employees' knowledge capital throughout the organization» (Bhojaraju, 2005, p. 37). Knowledge management helps members of an organization «collectively, systematically create, share, and apply knowledge to achieve their strategic and operational goals» (North \& Babakhanlou, 2016, p. 211). Knowledge management is often considered from two perspectives: the 
technological aspect that contributes to knowledge dissemination and the social context in which knowledge sharing takes place. As an important subset of knowledge management, «knowledge sharing is the acquisition, organization, reuse and transfer of experience-based knowledge and making that knowledge available to others» (Lin, 2006, p. 27). Teachers «must share knowledge among themselves so that they can pass it on to students, society and the world at large» (Adamseged \& Hong, 2018, p.27). Through knowledge sharing, experience-based knowledge is transmitted and made available to others (Lane, 2006). As such, in the present study, knowledge sharing refers to ESP teachers' collaborations to make the knowledge they have gained available to other teachers. It is in such a context that an organization's chances of survival increases (Argote et al., 2000). To do so, various platforms are available for knowledge sharing, including blogs, emails, online discussion groups, and forums. It does not matter which of these contexts is chosen, teacher-to-teacher interactions seem to be of particular importance.

Although English language teachers may participate in various teacher training courses in schools and language schools, teacher-teacher interactions have received less attention (Mawhinney, 2010). Teacher-teacher interactions can contribute to effective communication with other teachers and may lead to teachers developing new perspectives about their practice (Glazer et al. 2004; Ng \& Tan 2009). They can even contribute to «changes in cognition or behavior at the individual or group level» (Doppenberg, Bakx, \& Brok, 2012, pp. 548-549). Knowledge sharing through teachers' interactions may influence the development of teachers' reflective thinking (Kelchtermans, 2006; Vangrieken et al., 2015; Van Gyn, 1996) and change their classroom performance (Newmann, King, \& Youngs, 2000). Richards and Farrell (2005) explained that when teachers work together, they have a better chance of building knowledge, shaping it, and subsequently evolving their teaching methods. Teachers who meet regularly reflect on their teaching methods and those of their colleagues, and exchange ideas with each other (Hargreaves, 2013). Research has shown that teachers who participate in these groups develop more self-confidence, a stronger belief that they can make a difference in students' learning, a greater willingness to work collaboratively, and a greater commitment to changing their approach (Earley \& Porritt, 2010; Stoll et al., 2006). Knowledge sharing is an important factor for the success of organizations, and in scientific and academic environments it is an important element of the knowledge-based community (Trehan \& Kushwaha, 2012) and a factor for improving the professional performance of university teachers (Ramazanzade et al., 2019).

For over a century, the idea of organizational effectiveness has had a key role in organizational research. Scholars have suggested that an organization's social context has an influential effect on its effectiveness (Glisson, 2016), and as an important dimension of social context the term 'organizational climate' was introduced by Lewin (1939). According to Glisson (2016), Lewin "introduced the concept to demonstrate the psychological impact of the work environment on employees' sense of well-being, motivation, behavior, and performance" (p. 246). The organizational climate represents the social atmosphere of the educational context (Erturk \& Ziblim, 2020). In other words, it is the "mutually shared elements of an organization's culture that influence the behaviors and willingness to share knowledge" (Sveiby \& Simons, 2002, p.421). Organizational climate plays a key role in shaping the behaviors of an organization's members and has a significant effect on their perception of knowledge sharing (Chen \& Lin, 2004; Sveiby \& Simons, 2002). Negative organizational climates result in ineffective knowledge management programs (Davis \& Menzer, 2002). Different subscales of organizational climates like reward and support have a positive effect on knowledge management (Nazem, Mozaiini, \& Seifi, 2014).

The concept of organizational climate in schools has been examined by Hoy, Tarter, and Kottkamp (1991) and four different types of climates have been identified. The first type is an open climate. In such a climate, a high level of commitment, cooperation, and transparency can be found among the staff and they often receive support from the school administrator. Trust, openness in communication, understanding and supportive leadership, employee autonomy, and high productivity are distinctive characteristics of this type of climate. An engaged climate is the second type of climate. Here, the principal is in command, restricts teachers' behavior, and does not take care of teachers' needs. However, cooperation and interaction can be found among the teachers. The third type of climate is a disengaged climate. Although the principal has a supportive attitude toward the teachers, they do not voluntarily take responsibility. Finally, a closed climate is a threatening climate in which teachers do not exhibit high levels of commitment. Support and cooperation among the staff are at a low level and there is no trust among the staff. On top of that, an authoritarian atmosphere prevails in the educational setting where teachers are expected to obey the rules. 
A collaborative climate as one of the aspects of the general organizational climate may encourage individuals to share their knowledge. When there is a cooperative climate in an organization, members of a group are more willing to collaborate to share and develop knowledge. They also are inclined to coach other members' learning (Janz \& Prasarnphanich, 2003). In such an environment, individuals get together to discuss, reflect on shared experiences, and share knowledge (Lieberman, 1995). It is likely that when there is a cooperative climate in one's working environment, an employee is more inclined to compare himself/herself with other coworkers and behave in the same way (Buunk et al., 2005; Kelley \& Thibaut, 1978). Some common cultural activities carried out in a collaborative climate among faculty members are asking and answering questions, providing advice to colleagues, and requesting help (Tan, 2016). Accordingly, as Stoddart (2001) suggests, unless a culture that recognizes collaboration is implemented, knowledge sharing will not work.

Today, the use of knowledge sharing in the centralized educational institutions of developing countries like Iran is of paramount importance and it is necessary that universities institutionalize the culture of knowledge sharing in order to improve academics' performance (Jahani, Ramayah, \& Effendi, 2011). However, the success of knowledge sharing in an organization is contingent upon the existence of collaboration in the organizational culture (Sveiby \& Simons, 2002). On the other hand, there are challenges for instructors such as the highstakes curriculum and students' low learning motivation in ESP courses (Nezakatgoo \& Behzadpoor, 2017) coupled with ESP instructors' lack of expertise (Hayati, 2008), which can be dealt with when ESP instructors get involved in knowledge sharing. In this regard, some studies have been conducted on the relationship between organizational climate and knowledge sharing (e.g., Ghorbani Nia, \& Sadri, 2012; Rammatinia \& Maleki, 2013) in higher education; however, the power of knowledge sharing and interactions between teachers and university instructors has received less attention (Jong, Meirink, \& Admiraal, 2019; Sveiby \& Simons, 2002). Furthermore, to the best of our knowledge, no efforts have been made to examine the relationship between collaborative climate and knowledge sharing in higher education in Iranian universities in general and among ESP teachers in particular. To fill this gap, in the present study, with the aim of investigating the relationship between these two variables, the following research questions were formulated:

1. What is the attitude of ESP teachers toward knowledge sharing?

2. What is the status of an overall collaborative climate among ESP teachers?

3. Is there any relationship between collaborative climate and knowledge sharing among ESP teachers?

4. Does the collaborative climate predict ESP teachers' attitudes toward knowledge sharing?

5. If there is any relationship between collaborative climate and knowledge sharing, how does ESP teachers' collaborative climate contribute to their attitudes toward knowledge sharing?

\section{Materials and Methods}

\section{Procedure}

In the present study, a mixed methods approach was utilized. Accordingly, there were two phases in the present study. As for the first phase, a quantitative study was conducted at some private and state universities in Iran. ESP teachers were given two survey questionnaires that were designed to explore the attitudes of teachers toward knowledge sharing and a collaborative climate. In the second phase of the study, a semi-structured interview was conducted in order to the probe the contribution of teachers ' collaborative climate to their knowledge sharing.

In the quantitative phase, a questionnaire was employed to investigate if there is a collaborative climate in English departments among ESP teachers. Moreover, the relationship between collaborative climate and knowledge sharing was sought. Informed by the quantitative results, in the qualitative phase, one-to-one interviews were carried out with 13 ESP teachers to better understand the contributions of teachers " collaborative climate to EFL teachers' knowledge sharing.

\section{Participants}

Three hundred and twenty-eight ESP teachers (258 males and females 70) from different universities across Iran were recruited. The teachers were either ESP teachers at the time the research was carried out or had 
taught ESP at least two terms in the last five years in universities. The respondents' experience ranged from 7 to 19 years. One of the researchers who is a faculty member of a university collected data personally from the local campuses. As for far off campuses, the questionnaires were sent to the ESP teachers via Google Forms. Data were collected from July to August 2020. All participants gave informed consent to participate in the present study and they were reassured their information would remain confidential. As for the semi-structured interviews, 13 volunteer ESP teachers were recruited. Nine teachers were interviewed over the phone and four face-to-face interviews were conducted in either teacher lounges or in teachers' offices.

\section{Instruments}

As stated, there were two questionnaires in the present study. The first questionnaire investigated university instructors' attitudes towards knowledge sharing. The variables were measured using some of the items from the instruments developed by Kim and Ju (2008), Jolaee et al (2014), and Wangpipatwong (2009). In order to determine the construct validity of the knowledge sharing questionnaire, an exploratory factor analysis of the variables was performed with a number of 328 people. Before finalizing the factor analysis, it was examined and the result showed that out of 22 initially designed items, three items did not load into multiple clusters or had a weak bond with a cluster or belonged to a low-quality factor. In addition, the number of items of one component was lower than the standard. Therefore, the analysis was performed for a second time. The final instrument consisted of 19 items and included six subscales namely, awareness (3 items), trust (5 items), willingness to share (3 items), self-efficacy ( 3 items), organization culture ( 3 items), and reward system (2 items). Cronbach's alpha coefficient for all 19 items on the scale was 0.738 , which indicates that the items highly correlate with each other. In other words, from the obtained values, it can be concluded that the questionnaire had the necessary research construct validity.

The second questionnaire explored the collaborative climate among university teachers. The original scale was developed by Sveiby and Simons (2002). Some changes were made in the items to make them suitable for educational contexts. The scale consists of 20 items with four subscales: organizational context (5 items), the head of department (5 items), teachers' attitudes (5 items), and workgroup support (5 items). The results of Cronbach's alpha coefficient obtained after factor analysis was equal to .868 .

To explore the contribution of teachers' collaborative climate to their knowledge sharing, 13 interviews were conducted with volunteer ESP teachers. It should be noted that among all of the participants, 25 agreed or had the chance to take part in the interview, but only 13 were present on the day of the interview.For validity purposes, two experts in TEFL were invited to review the interview questions and the guidelines for the interview. To give the interviewees the opportunity to express their ideas freely, the interviews were carried out in Farsi. Each interview was translated to English by the first researcher, then the transcripts were transcribed and coded.

\section{Data collection and data analysis procedure}

The statistical population of the study included Iranian ESP teachers. To determine the sample size, we used Krejcie and Morgan's table (1970). Then, 384 questionnaires were distributed in hard copy or by e-mail. Because of Covid- 19 lockdown, only 16 teachers received the hardcopies at their universities. They were then reduced to 328 copies after incomplete or carelessly completed surveys were discarded. To compute the collected data, SPSS 23 was used.

Before conducting the Pearson correlation, descriptive statistics were run in order to identify the attitude of ESP teachers toward knowledge sharing and find out if there was a collaborative climate in English departments among ESP teachers. In addition, a multiple regression analysis was used to determine if a collaborative climate could predict ESP teachers' attitudes toward knowledge sharing. Once the relationship between teachers' collaborative climate and knowledge sharing was established through Pearson correlation, a semi-structured interview was conducted in Farsi, which was later translated into English, and subjected to thematic analysis. These analyses aimed at identifying themes (Braun \& Clarke, 2006; Dornyei, 2007). To do so, the common patterns emanating from the data were coded. Then, the emerging themes were subjected to frequency analysis and finally tabulated. 


\section{Results}

The demographic characteristics of the study showed that out of 328 faculty members, 121 were females and 207 were males. In terms of academic rank, 90 were M.A. holder instructors, 207 were assistant professors, and 31 were associate professors.

To answer the first and second research questions, we inquired about the attitudes of the teachers towards knowledge sharing and the overall status of the collaborative climate. The overall scores and the subscales of the two instruments are summarized in Table 1.

\section{Table 1}

Descriptive statistics of subscales of knowledge sharing and collaborative climate

\begin{tabular}{llcc}
\hline \multicolumn{1}{c}{ Variables } & \multicolumn{1}{c}{ Subscale } & Mean & Std. Deviation \\
\hline \multirow{2}{*}{ Knowledge sharing } & Awareness & 3.13 & .791 \\
& Trust & 3.05 & .597 \\
& Willingness to share & 3.10 & 1.113 \\
& Self- efficacy & 2.96 & .836 \\
& Organization culture & 3.02 & .834 \\
& Reward system & 3.08 & .802 \\
& Knowledge sharing (Total) & 3.06 & .431 \\
\hline \multirow{2}{*}{ Collaborative climate } & Organizational culture & 3.13 & .730 \\
& Heachers' attitude & 3.06 & .637 \\
& Workgroup support & 2.91 & .641 \\
& Collaborative climate (Total) & 3.05 & .620 \\
& & 3.11 & .375 \\
\hline
\end{tabular}

According to Table 1, the average knowledge sharing in the sample group was 3.06 with a standard deviation of .431 , which was at the theoretical average (3). Considering the participants' assessment of knowledge sharing variables, their overall mean scores on awareness, trust, willingness to share, self- efficacy, organization culture, and reward system were, respectively, $3.13(\mathrm{SD}=.791), 3.05(\mathrm{SD}=.597), 3.10(\mathrm{SD}=1.113), 2.96(\mathrm{SD}=.836)$, and $3.08(\mathrm{SD}=.802)$.

The average collaborative climate in the sample group was 3.05 with a standard deviation of .375 , which was at the theoretical average (3). Considering the participants' assessment of collaborative climate variables, their overall mean scores on organizational culture, the head of department, teachers' attitudes, and workgroup support were, respectively, $3.13(\mathrm{SD}=.730), 3.06(\mathrm{SD}=.637), 2.91(\mathrm{SD}=.641)$, and $3.11(\mathrm{SD}=.620)$.

Figures 1 and 2 illustrate the views of each subscale on the collaborative climate and knowledge sharing questionnaires.

The third research question examined if there is any relationship between collaborative climate and knowledge sharing among ESP teachers. A Pearson correlation coefficient test was used to answer the question. The results of this test are shown in Table 2. 


\section{Figure 1}

Collaborative climate subscales

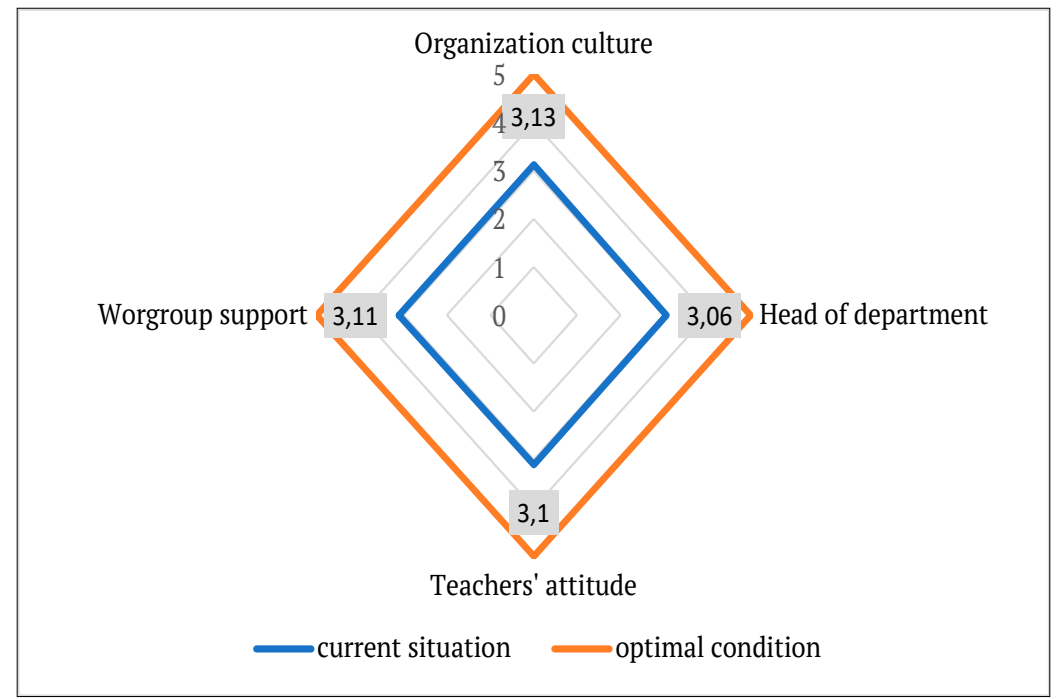

Figure 2

Knowledge sharing subscales

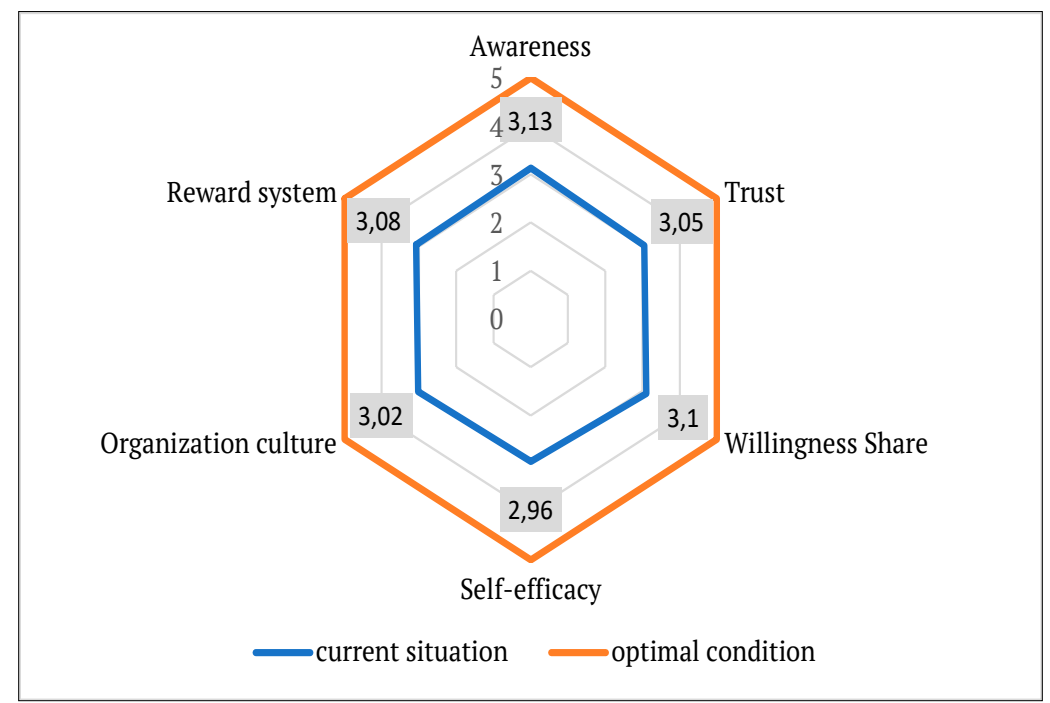

Table 2, which illustrates the Pearson correlations, indicated a strong positive correlation between the variables of organizational culture $(r=.449, \mathrm{p}<.000)$, the head of department $(r=.470, \mathrm{p}<.000)$, teachers' attitudes $(\mathrm{r}=$ $.485, \mathrm{p}<.000)$, workgroup support $(\mathrm{r}=.460, \mathrm{p}<.000)$, and generally a collaborative climate score $(\mathrm{r}=0.734, \mathrm{p}<$ 0.000 ) with knowledge sharing.

The fourth research question explored whether collaborative climate predicts ESP teachers' attitudes towards knowledge sharing. In order to answer this research question, a multiple regression test was used. Test results based on the collaborative climate subscales are displayed in Table 3. 
Table 2

Pearson correlations of collaborative climate (organizational culture, the head of department, teachers' attitude, workgroup support) and knowledge sharing

\begin{tabular}{|c|c|c|c|c|c|c|c|}
\hline & & 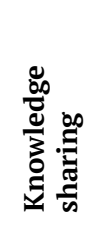 & 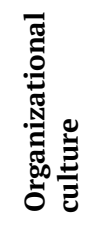 & 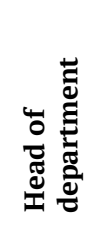 & 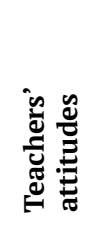 & 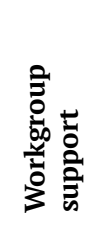 & 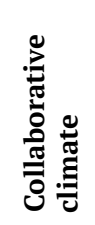 \\
\hline \multirow{2}{*}{ Knowledge sharing } & Pearson Correlation & \multirow{2}{*}{1} & $.449 * *$ & $.470^{* * *}$ & $.485^{* * *}$ & $.460^{* * *}$ & $.734^{* * *}$ \\
\hline & Sig. (2-tailed) & & .000 & .000 & .000 & .000 & .000 \\
\hline \multirow{2}{*}{$\begin{array}{l}\text { Organizational } \\
\text { culture }\end{array}$} & Pearson Correlation & $.449^{* * *}$ & \multirow{2}{*}{1} & $.496 * *$ & $.174^{* * *}$ & $.143 * *$ & $.733^{* * *}$ \\
\hline & Sig. (2-tailed) & .000 & & .000 & .002 & .010 & .000 \\
\hline \multirow{2}{*}{ Head of department } & Pearson Correlation & $.470 * *$ & $.496 * *$ & \multirow{2}{*}{1} & .051 & $.180 * *$ & $.635^{* * *}$ \\
\hline & Sig. (2-tailed) & .000 & .000 & & .354 & .001 & .000 \\
\hline \multirow{2}{*}{ Teachers' attitudes } & Pearson Correlation & $.485^{* * *}$ & $.174^{* * *}$ & .051 & \multirow{2}{*}{1} & $.164^{* * *}$ & $.571^{* * *}$ \\
\hline & Sig. (2-tailed) & .000 & .002 & .354 & & .003 & .000 \\
\hline \multirow{2}{*}{ Workgroup support } & Pearson Correlation & $.460^{* * *}$ & $.143^{* * *}$ & $.180^{* * *}$ & $.164^{* * *}$ & \multirow{2}{*}{1} & $.588^{* * *}$ \\
\hline & Sig. (2-tailed) & .000 & .010 & .001 & .003 & & .000 \\
\hline \multirow{2}{*}{$\begin{array}{l}\text { Collaborative climate } \\
\text { (Total) }\end{array}$} & Pearson Correlation & $.734^{* * *}$ & $.733^{* * *}$ & $.635^{* *}$ & $.571^{* * *}$ & $.588^{* * *}$ & \multirow{2}{*}{1} \\
\hline & Sig. (2-tailed) & .000 & .000 & .000 & .000 & .000 & \\
\hline
\end{tabular}

**. Correlation is significant at the 0.01 level (2-tailed).

Table 3

Coefficients (Predictor variable: knowledge sharing)

\begin{tabular}{|c|c|c|c|c|c|c|c|c|c|}
\hline & \multirow{2}{*}{$\begin{array}{c}\text { Model } \\
\text { B }\end{array}$} & \multicolumn{2}{|c|}{$\begin{array}{l}\text { Unstandardized } \\
\text { Coefficients }\end{array}$} & \multirow[t]{2}{*}{$\begin{array}{c}\text { Standardized } \\
\text { Coefficients }\end{array}$} & \multirow{2}{*}{$\mathbf{t}$} & \multirow{2}{*}{$\begin{array}{c}\text { Sig. } \\
\text { Zero-order }\end{array}$} & \multicolumn{3}{|c|}{ Correlations } \\
\hline & & $\begin{array}{l}\text { Std. } \\
\text { Error }\end{array}$ & Beta & & & & Partial & Part & \\
\hline \multirow{5}{*}{1} & (Constant) & 1.261 & .098 & & 12.821 & .000 & & & \\
\hline & Organizational culture & .087 & .020 & .189 & 4.362 & .000 & .449 & .236 & .162 \\
\hline & Head of department & .192 & .028 & .300 & 6.959 & .000 & .470 & .361 & .258 \\
\hline & Teachers' attitudes & .192 & .019 & .385 & 10.106 & .000 & .485 & .490 & .374 \\
\hline & Workgroup support & .163 & .020 & .316 & 8.276 & .000 & .460 & .418 & .306 \\
\hline \multicolumn{2}{|c|}{$\mathrm{R}=.746$} & $=.557$ & & Adj. $=.552$ & & & & & \\
\hline \multicolumn{2}{|c|}{$F=101.582$} & Sig. $=.000$ & & $\mathrm{df}=4$ & & & & & \\
\hline
\end{tabular}

According to Table 3, the results of the multiple regression analysis show that $\mathrm{R}$ is equal to 0.746 . That is, the Pearson correlation between the predicted values and the actual value of the dependent variable is .746. The coefficient R2 represents the value of the explained variance of the independent predictor variable, which here is equal to .557. In other words, the variance of the intervening variable as determined by the model showed that the variable stands for 55 percent of the variance of the criterion variable (knowledge sharing). The results of ANOVA revealed that the observed $\mathrm{F}$ is equal to $101.582(\mathrm{df}=4)(\mathrm{P}=.000<.05)$, which the level of $\mathrm{F}$ at the .05 level of significance. There is a $95 \%$ probability that there is a significant relationship between a collaborative climate and knowledge sharing. Table 3 also shows the knowledge sharing prediction coefficients using these predictor variables. There are four predicting independent variables due to a collaborative climate including: organizational culture, the head of department, teachers' attitudes, and workgroup support containing $p<.05$; therefore, the Alpha level that statistically explains the variance of knowledge sharing is .05 . The $\beta$ standard correlation shows that the effective correlation of organizational culture is $(\beta=.189 ; \mathrm{t}=4.362)$ and the 
correlation of the head of department is $(\beta=.300 ; t=6.959)$, the affective correlation of teachers' attitudes is $(\beta=$ $.385 ; \mathrm{t}=10.106)$, and the effective correlation of workgroup support is $(\beta=.316 ; \mathrm{t}=8.276)$, which explain knowledge sharing.

The results of the correlation partially showed that the variables of organizational culture (5.56\%), the head of department (13.03\%), teachers' attitudes (24.01\%), and workgroup support (17.47) explain knowledge sharing.

Table 4 shows the results of the multiple regression test. It should be noted that the main variable of this research question is a collaborative climate.

\section{Table 4}

Coefficients Predictor variable: knowledge sharing

\begin{tabular}{|c|c|c|c|c|c|c|c|c|c|}
\hline & \multirow{2}{*}{$\begin{array}{l}\text { Model } \\
\text { B }\end{array}$} & \multicolumn{2}{|c|}{$\begin{array}{l}\text { Unstandardized } \\
\text { Coefficients }\end{array}$} & \multirow[t]{2}{*}{$\begin{array}{l}\text { Standardized } \\
\text { Coefficients }\end{array}$} & \multirow{2}{*}{$\mathbf{t}$} & \multirow{2}{*}{$\begin{array}{c}\text { Sig. } \\
\text { Zero-order }\end{array}$} & \multicolumn{3}{|c|}{ Correlations } \\
\hline & & $\begin{array}{l}\text { Std. } \\
\text { Error }\end{array}$ & Beta & & & & Partial & Part & \\
\hline \multirow{2}{*}{1} & (Constant) & 1.342 & .096 & & 14.031 & .000 & & & \\
\hline & collaborative climate & .605 & .031 & .734 & 19.510 & .000 & .734 & .734 & .734 \\
\hline \multicolumn{2}{|c|}{$\mathrm{R}=.734$} & $=.539$ & & Adj. $=.537$ & & & & & \\
\hline \multicolumn{2}{|c|}{$F=26.107$} & Sig. $=.000$ & & $\mathrm{df}=1$ & & & & & \\
\hline
\end{tabular}

Table 2, which illustrates the results of the multiple regression analysis, indicates that $\mathrm{R}$ is equal to .734 . That is, the Pearson correlation between the predicted values and the actual value of the dependent variable is .73. The coefficient R2 represents the value of the explained variance of the independent predictor variable, which here is equal to .539. In other words, the variance of the intervening variable as determined by the model showed that the variable stands for 53 percent of the variance of the criterion variable (knowledge sharing). The results of ANOVA revealed that the observed $\mathrm{F}$ is equal to $26.107(\mathrm{df}=1)(\mathrm{P}=.000<.05)$, which the level of $\mathrm{F}$ at the .05 level of significance. There is a $95 \%$ probability that there is a significant relationship between a collaborative climate and knowledge sharing. Table 4 also shows the knowledge sharing prediction coefficients using the predictor variables. There are four predicting independent variables due to a collaborative climate including: organizational culture, the head of department, teachers' attitudes, and workgroup support containing $\mathrm{p}<.05$; Therefore, the Alpha level that statistically explains the variance of knowledge sharing is .05 . The $\beta$ standard correlation shows that the effective correlation of collaborative climate is $(\beta=.734 ; t=19.510)$. The results of the correlation showed that the variable of a collaborative climate $(53.87 \%)$, as a predictor variable, explains the knowledge sharing.

The fifth research question inquired about the contribution of teachers' collaborative climate to their knowledge sharing. Since the interviews were carried out after the results of the quantitative phase were clear, we mainly concentrated on discovering the reasons behind the collaborative climate among university ESP teachers. The following section presents the findings.

The most recurrent theme extracted from the data was a helpful atmosphere and positive organizational culture among the ESP teachers. As reported, the interviewees had a positive attitude toward a collaborative climate. More specifically, they expressed their positive feelings about the culture in their department. This is vividly echoed in the following statement by a teacher.

"Where I'm working, nobody keeps to himself. I think everybody is seeking opportunities to have interactions with colleagues."

The contribution of culture to teachers' knowledge sharing is illustrated in another interviewee's report.

"They are eager to share information with others. I also see a lot of motivation to communicate with other ESP teachers. I always think about a university in which the academics are willing to meet each other and share necessary information in workshops or informal gatherings". 
Another young interviewee acknowledged his positive view towards information sharing among colleagues; however, as he claimed, young inexperienced teachers are more willing to be actively involved in knowledge sharing than more experienced ones. This lack of communication between experienced as less experienced colleagues, among other reasons, maybe due to the more experienced academics fearing knowledge loss, and maintaining power and a competitive advantage. This is manifested in the following statement:

“...They [the more experienced ESP teachers] think that what they know or the papers they have published is their intellectual property and they are reluctant to share them with others, as if they are keeping a secret from other people".

Another reason behind the collaborative climate expressed by all of the interviewees was that the universities and heads of departments expected or encouraged knowledge sharing among academics. The ESP teachers considered the heads of department to be empowering and supportive. For them, their head of department never adopted a laissez-faire approach that is a form of passive leadership (Yukl, 2013). In addition, as reported, there was a commitment on the part of the head of department and an emphasis on the fulfillment of duties. As one ESP teacher commented:

«We meet the head of department at regular intervals, about once a month in her office. Not only do we often receive instruction on the curriculum through social networks such as WhatsApp, but we often have informal chats on a variety of issues we encounter in our daily practice in the social network. The chats are often led by her [the head of the department] «.

Another interviewee stated that:

"The group manager has created a WhatsApp channel for professors. It is used for sharing ideas and to send necessary news about rules and regulations».

The expectation of reward as an individual factor was also considered by the interviewees as a factor that contributes to knowledge sharing among ESP teachers. Two interviewees highlighted the fact that they received verbal rewards whenever they engaged in knowledge sharing.

"We may often share knowledge through informal contacts we have in the teacher lounge or WhatsApp.

Such an interaction has often been encouraged by the university or the head of the department".

Such a statement shows the importance of motivational issues in creating a positive culture and hence building successful knowledge activities in universities.

Another form of reward, as one interviewer stated, was the reputation she received as the result of knowledge sharing. She felt that after taking part in a discussion, her colleagues respected her more.

Workgroup support among ESP teachers was another contributing factor to knowledge sharing behavior based on the report of ESP teachers.An interviewee commented:

"You can expect support from your colleagues. There is often communication between the colleagues and we meet each other during the tea break in the teachers' lounge. When you cannot discuss the problem there, social media gives you the opportunity to be in contact with your colleagues after work to receive help.

Another interviewee commented:

"The exchange of knowledge can take place among colleagues through face-to-face communication; however, the time at the university is short, so, the head of department has only enough time to inform us about current events and trends. However, there are times we join in the group and discuss the problems while the head of department is away".

\section{Discussion}

The present study investigated the attitude of ESP teachers toward knowledge sharing and the status of the overall collaborative climate among ESP teachers. It also sought to understand the relationship between ESP teachers' collaborative climate and their attitudes toward knowledge sharing. 
With respect to the first and second research questions, the descriptive data showed the status of a collaborative climate and knowledge sharing among ESP teachers. The results indicated that the attitudes towards knowledge sharing and the status of a collaborative climate were desirable among the ESP teachers since they made efforts to build cohesion and teamwork in a collaborative climate. The finding is in line with that of Fullwood, Rowley, and Elbridge (2013) who reported that academics had a positive attitude towards knowledge sharing. Esmaell Panah and Khayat Mogadam (2013), who investigated knowledge sharing among university teachers of a public university in Iran, also reported that the teachers engaged in an acceptable level knowledge sharing. In the same vein, Alizadeh (2009) explored agricultural faculty members' attitudes toward knowledge sharing and found a positive attitude among them.

The result was also in tandem with the findings of Jahanbani et al. (2018) conducted in a medical university in Iran. However, the findings are in contrast to those of Nemati-Anaraki and Nooshinfard (2014) and Nejadhussein and Azadbakht (2011). Nemati-Anaraki and Nooshinfard found that only 13 percent of faculty members reported that their organizational culture was appropriate and only six percent regarded the condition of knowledge sharing favorable. Nejadhussein and Azadbakht (2011), who studied knowledge sharing among the faculty members of a state university, also found the university to be weak regarding knowledge sharing among faculty members. Perhaps, among various possible reasons, the contradictory results can be attributed to the fact that these studies were conducted in different universities where each department may have its own specific culture.

The third research question investigated if there was any relationship between a collaborative climate and knowledge sharing among ESP teachers and the fourth research question explored if a collaborative climate predicts ESP teachers' attitudes toward knowledge sharing. Significant positive correlations were found for four measures (organizational culture, the head of department, teachers' attitude, workgroup support) and in general the collaborative climate. In addition, it was revealed that collaborative climate predicts ESP teachers' attitudes toward knowledge sharing. Various studies have demonstrated that certain types of cultures support knowledge sharing initiatives whereas others do not (Ahmed, et. al., 2016). Our finding can be corroborated by Ghorbani Nia and Sadri's (2012) and Rammatinia and Maleki's (2013) in that they found a significant relationship between knowledge management and organizational climate in Iranian higher education. Similar results were reported in fields other than higher education (Connelly \& Kelloway, 2003; Han, 2018; Hooff \& Huysman, 2009; Joseph \& Jacob, 2011). The result can be justified by the consideration that both organizational culture and knowledge sharing are cultural values that influence the patterns of individuals' cognitive frameworks and knowledge sharing behaviors (Cheng, Yeh, \& Tu, 2008). This implies that a cooperative working environment can be cultivated among university faculty members and they can be encouraged to cooperate with others in research teams in their departments. By so doing, high levels of knowledge sharing may be fostered among teachers. A feasible justification for this is that a collaborative climate may result in favorable social interactions and, in turn, lead to a higher degree of knowledge sharing among teachers. Therefore, social interactions play a key role in the relationship between a collaborative climate and knowledge sharing.

To answer the fifth research question, the qualitative phase supported the findings of the quantitative phase in that a positive organizational culture was found to exist among the ESP teachers. More specifically, values and beliefs held by the teachers may have a great influence on their decision-making processes (Bartell, 2003; Tierney, 1988) and shaped their organizational behaviors. Based on the content analysis, the key themes extracted from the data included helpful atmosphere, support received from the heads of departments, the expectation of reward, and workgroup support.

One of the themes extracted from the data was a helpful atmosphere and positive organizational culture. It is noteworthy that culture can be considered as the most significant organizational factor affecting knowledge sharing (Lee, Shiue, \& Chen, 2016). Also, in order to benefit from its knowledge-based resources, an organization should cultivate a culture that develops a positive organizational culture (Davenport \& Prusak, 1998; Greiner, Böhmann, \& Krcmar, 2007). The studies carried out in the Iranian context have revealed that good social relationships among members of an organization support their knowledge sharing (Dokhtesmati, 2012; Khatamianfar \& Ghorbani Bousari, 2013; Pezeshkirad, Alizadeh, \& Zamani Miandashti, 2010). It was not surprising to find that some of more experienced teachers were not willing to get involved in knowledge sharing with less experienced teachers. In this regard, von Krogh (1998) explained that mentoring programs under the supervision of the organization enable seniors to help juniors. Accordingly, senior members should be 
encouraged to share their knowledge and experience with other colleagues. In addition, as suggested by AlKurdi et al. (2018), university officials can enhance positive attitudes toward knowledge sharing by addressing experienced and more knowledgeable professors" "fear of losing knowledge power and by reassuring their position and value in the institution" (p.239).

Based on the results gleaned from the interview, heads of departments contributed to the teachers' sharing of knowledge. As suggested in several studies, knowledge management practices could be developed if the top management shows degrees of commitment (Hislop, 2003; Rowley, 2002; Xue, Bradley, \& Liang, 2011). In addition, without the support provided by the leadership, an organization will not achieve effective knowledge management (Al-Kurdi et al., 2018; Fullwood et al., 2013). It has also been demonstrated that there is a relationship between leadership and knowledge sharing behavior (Connelly \& Kelloway, 2003; Jahani et al., 2011) and that in cases of conflict between managers and academics, knowledge sharing may be inhibited (Dee \& Leisyte, 2017). Despite the common constraints in knowledge management, it is believed that the hurdles to knowledge sharing among teachers can be eradicated by effective leadership (Collinson, 2004; Fullan, 2002). Such a role may result in beneficial consequences for knowledge sharing in Iranian education (Zeinabadi, 2020), especially in higher education.

Another theme that emerged in the present study was the expectation of reward. Reward plays an effective role in knowledge sharing (O’Dell \& Hubert, 2011) in general and at the university level, in particular (Kim \& Ju, 2008). In other words, unless there are strong personal motivations to share knowledge, people are more likely to hoard it (Ford \& Staples, 2010; Loebbecke, Van Fenema, \& Powell, 2016). As such, top management needs to motive university professors to share knowledge by giving them required training, resources, and substantial rewards, especially at the early stages. This may contribute to teachers' being aware of the possible benefits and make more effort to get involved in knowledge sharing (Ahmed et al., 2016).

Finally, based on the content analysis, workgroup support had a positive effect on teachers' knowledge sharing, and the ESP teachers in this study reported that they are usually encouraged to form informal gatherings, research groups, and discussion forums to share knowledge. Workgroup support has a significant impact on the intention of sharing knowledge (Mooghali, 2012). Such support may be manifested in different forms. As Denhardt (1984) suggests, in a collaborative culture, employees make collective efforts for creating teamwork and try to be helpful, sensitive, open, and fair.

\section{Conclusion}

This study concluded that ESP teachers' collaborative climate was a predictor of their attitudes toward knowledge sharing. This means that the academics who are actively involved in a collaborative climate are more likely to take part in knowledge sharing with their colleagues. Thus, due to the importance of knowledge and in order to cultivate the dissemination of knowledge among university teachers, university policies and practices providing conditions for teachers' interactions in and outside the university should encourage team working, informal gatherings, workshops, and interactive teacher training courses.As such, based on our research findings, the present study offers several practical recommendations and implications for ESP teachers:

1. It is obvious that much energy and time are required to change the status quo and encourage teachers to adopt positive attitudes towards cooperative work; however, in-service teacher training may raise teachers' awareness as to the necessity of teachers working together. To do so, it seems necessary to draw teachers' attention to both 'knowing that', and 'knowing how'.

2. Teacher learning communities are highly affected by the culture of the learning environment. As such, university teachers should be aware of opportunities and conflicts that arise as the result of interactions with the environment since the conflicts may mediate or hinder learning.

3. Cultivating either formal or informal teacher learning communities in university departments may contribute to a positive attitude towards the organizational climate and ultimately act as a motivating factor towards sharing knowledge. 
The present study explored the relationship between a collaborative climate and knowledge sharing among ESP teachers; however, it did not consider the differences between faculty members and adjunct instructors. Adjunct instructors make up a portion of university faculties in Iranian universities and it is likely that there are differences in motivation, institutional support, job satisfaction, effectiveness in teaching, objectives, and teaching practices between tenure-track instructors and part-time adjunct ones (Bolitzer, 2019). Further study can recruit a sample representative of both populations and compare the effect of a collaborative climate on them. Another limitation of the study was that even the teachers who had at least two terms of experience teaching ESP were included as participants. This limited the validity of the findings since there is the possibility that some of the participants were not experienced enough to present a valid description of their opinions.

\section{Acknowledgments}

The researchers appreciate all of the ESP teachers who participated in the study.

\section{Conflict of Interest}

The authors declare that they have no conflicts of interest.

\section{References}

Adamseged, H. Y., \& Hong, J. J. (2018). Knowledge sharing among university faculty members. Journal of Education and Practice, 9(24), 1-10.

Ahmed, F., Shahzad, K., Aslam, H., Bajwa, S. H., \& Bahoo, R. (2016). The role of collaborative culture in knowledge sharing and creativity among employees. Pakistan Journal of Commerce and Social Sciences, 10(2), 335-358.

Alizadeh, N. (2009). Investigating the attitude of the members of the faculty about KS in educational institutions: A case studyo f agriculture faculties in Tehran and Tarbiat Modarres universities \{Unpublished Mastre's Thesis]. Tarbiat Modarres University.

Al-Kurdi, O., El-Haddadeh, R., \& Eldabi, T. (2018). Knowledge sharing in higher educationinstitutions: A systematic review. Journal of Enterprise Information Management, 31(2), 226-246. https://doi.org/10.1108/ JEIM-09-2017-0129.

Argote, L., McEvily, B., \& Reagans, R. (2003). Managing knowledge in organizations: an integrative framework and review of emerging themes. Management Science, 49(4), 571-582. https://doi.org/10.1287/ mnsc.49.4.571.14424

Avarzamani, F., \& Farahian, M. (2019). An investigation into EFL learners' reflection in writing and the inhibitors to their reflection. Cogent Psychology, 6(1), 1-13. https://doi.org/10. 1080/23311 908.2019.1690817

Bartell, M. (2003). Internationalization of universities: A university culture-based framework. Higher Education, 45(1), 43-70. https://doi.org/10.1023/A:1021225514599

Bhojaraju, G. (2005). Knowledge management: Why do we need it for corporates? Malaysian Journal of Library \& Information Science, 10(2), 37-50. https://doi.org/10.2139/ssrn.3375572

Bock, G., \& Kim, Y. G. (2002). Breaking the myths of rewards: an exploratory study of attitudes about knowledge sharing. Information Management Resources Journal, 15(2), 14-21. https://doi.org/10.4018/irmj.2002040102.

Bolitzer, L. A. (2019). What we know (and don't know) about adjunct faculty as teachers at four-year institutions. The Review of Higher Education, 43(1), 13-142. https://doi.org/ 10.1353/rhe. 2019.0092.

Braun, V., \& Clarke, V. (2006). Using thematic analysis in Psychology. Qualitative Research in Psychology, 3(2), 77-101. https://doi.org/10.1191/1478088706qp063oa

Buunk, B. P., Zurriaga, R., Peíró, J. M., Nauta, A., \& Gosalvez, I. (2005). Social comparisons at work as related to a cooperative social climate and to individual differences in social comparison orientation. Applied Psychology, 54(1), 61-80. https://doi.org/10.1111/j.1464-0597.2005.00196.x

Chen, C., \& Lin, B. (2004). The effects of environment, knowledge attribute, organizational climate, and firm characteristics on knowledge sourcing decisions. $R \& D$ Management, 34(2), 137-146. https://doi.org/10.1111/ j.1467-9310.2004.00329.x

Chen, C. J., \& Huang, J-W. (2007). How organizational climate and structure affect knowledge management-the social interaction perspective. International Journal of Information Management, 27(2), 104-118. https://doi. 
org/10.1016/j.ijinfomgt.2006.11.001

Cheng, J. H., Yeh, C. H., \& Tu, C. W. (2008). Trust and knowledge sharing in green supply chains. Supply Chain Management: An International Journal, 13(4), 283-295. https://doi.org/10 .1108/ 13598540810882170

Collinson, V. (2004). Learning to share, sharing to learn: fostering organizational learning through teachers' dissemination of knowledge. Journal of Educational Administration, 42(3), 312-332. https://doi. org/10.1108/09578230410534658

Connelly, C. E., \& Kelloway, E. K. (2003). Predictors of employees' perceptions of knowledge sharing cultures. Leadership \& Organization Development Journal, 24(5), 294-301.https://doi.org/10. 1108/01437730310485815

Davenport, T. H., \& Prusak, L. (1998). Working knowledge: Managing what your organization knows. Harvard Business School Press.

Davis, D. F., \& Mentzer, J. T. (2002). Organizational climate, knowledge management, and performance: An integrative framework. American Marketing Association.

Dee, J., \& Leisyte, L. (2017). Knowledge sharing and organizational change in higher education. The Learning Organization, 24(5), 1-12. https://doi.org/10.1108/TLO-04-2017-0034

Doppenberg, J. J., Bakx, A. W. E. A., \& Brok, den, P. J. (2012). Collaborative teacher learning in different primary school settings. Teachers and Teaching, 18(5), 547-566. https://doi.org/10.10 80/13540602.2012.709731

Denhardt, R. B. (1984). Theories of public organization. Cole.

Dokhtesmati, M. (2012). Investigating the usage of KS in developing university libraries website of Tehran city and World the role of librarians on it: Presenting proposed model [Unpublished Master's thesis]. Islamic Azad University.

Dornyei, Z. (2007). Research methods in applied linguistics: Quantitative, qualitative, and mixed methodologies. Oxford University Press.

Earley, P., \& Porritt, V. (2010). Effective practices in continuing professional development: Lessons from schools. University of London.

Erturk, A., \& Ziblim, L. (2020). Is the perception of organizational deviation affected by the organizational climate? Research in schools. Eurasian Journal of Educational Research, 20(85), 1-22.

Esmaell Panah, F., \& Khayat Mogadam, S. (2013). Surveying the current status of knowledge sharing among faculty members of universities. The Journal of Productive Management, 3(26), 43-68.

Farahian., Avarzamani, F., \& Rajabi, Y. (2021). Reflective thinking in an EFL writing course: To what level do portfolios improve reflection in writing? Thinking Skills and Creativity, 39(1), 100759. https://doi.org/10.1016/j. tsc.2020.100759

Ford, D. P., \& Staples, S. (2010). Are full and partial knowledge sharing the same? Journal of Knowledge Management, 14(3), 394-409. https://doi.org/10.1108/13673271011050120

Fullan, M. (2002). The role of leadership in the promotion of knowledge management in schools. Teachers and teaching: Theory and practice, 8(3), 409-419. https://doi.org/10.1080/13540600 2100000530

Fullwood, R., Rowley, J., \& Delbridge, R. (2013). Knowledge sharing amongst academics in UK universities. Journal of Knowledge Management, 17(1), 123-136. https://doi.org/10.1108/13673 271311300831

Ghonsooly, B., \& Pishgadam, R. (2011). A critique on ESP books: Examining general English at university level. Quarterly Journal of Language and Translation Studies, 42(3), 21-36.

Ghorbani, M., Nia, K. R., \& Sadri, F. (2012). The relationship between knowledge management and organizational climate. World Applied Sciences Journal, 18(5), 652-658. https://doi.org/10.5829/idosi.wasj. 2012.18.05.1367

Glazer, C., Abbott, L., \& Harris. J. (2004). A teacher-developed process for collaborative professional reflection. Reflective Practice, International and Multidisciplinary Perspectives, 5(1), 33-46. https://doi. org/10.1080.1462394032000169947

Glisson, C. (2015). The Role of organizational culture and climate in innovation and effectiveness. Human Service Organizations: Management, Leadership \& Governance, 39(4), 245-250. https://doi.org/10.1080/23303131.20 15.1087770

Goh, S. K., \& Sandhu, M. S. (2013). Knowledge sharing among Malaysian academics:Influence of affective commitment and trust. The Electronic Journal of Knowledge Management, 11(1), 38-48.

Greiner, M. E., Böhmann, T., \& Krcmar, H.(2007). A strategy for knowledge management. Journal of Knowledge Management, 11(6), 3-15. https://doi.org/10.1108/13673270710832127

Han, S. H. (2018). The antecedents and dimensionality of knowledge-sharing intention: an empirical study of R \& D Engineers in high-performing IT company. European Journal of Training and Development, 42(1/2), 125142. https://doi.org/10.1108/EJTD-09-2017-0073

Hargreaves, E. (2013). Assessment for learning and teaching learning communities: UK teachers' experiences. Teaching Education, 24(3), 327-344. https://doi.org/10.1080/10476210.2012.713 931 
Hayati, A. M. (2008). Teaching English for special purposes in Iran: Problems and suggestions. Arts and Humanities in Higher Education, 7(2), 149-164. https://doi.org/10.1177/1 4740222 08088645

Hislop, D. (2003). Linking human resource management and knowledge management via commitment: A review and research agenda. Employee Relations, 25(2), 182-202. https://doi.org/10.1108/01425450310456479

Hooff, B., \& Huysman, M. (2009). Managing knowledge sharing: Emergent and engineering approaches. Information and Management, 46(1), 1-8. https://doi.org/10.1016/j.im.2008.09.002

Hoy, W. K., \& Tarter, C. J. (1997). The road to open and healthy schools: A handbook for change. Corwin.

Jahanbani, E., Davoodi, M., LotfiZadeh, Z., \& Zozani, M. A. (2018). Knowledge management and its influencing factors in Ahvaz Jndishapur University of medical sciences. Journal of JundiShapur Educational Development, 9(2), 120-128.

Jahani, S., Ramayah, T., \& Effendi, A. A. (2011). Is reward system and leadership important in knowledge sharing among academics? American Journal of Economics and Business Administration, 3(1), 87-94. https:// doi.org/10.3844/ajebasp.2011.87.94

Janz, B.D., \& Prasarnphanich, P. (2003). Understanding the antecedents of effective knowledge management: The importance of a knowledge-centered culture. Decision Sciences, 34(2), 351-384. https://doi.org/10.1111/15405915.02328

Jolaee, A., Nor, K. H., Khani, N., \& Yusoff, R. M. (2014). Factors affecting knowledge sharing intention among academic staff. International Journal of Educational Management, 28(4), 13 -431. https://doi.org/10.1108/ IJEM-03-2013-0041

Jong, L. de, Meirink, J., \& Admiraal, W. (2019). School-based teacher collaboration: Different learning opportunities across various contexts. Teaching and Teacher Education, 86, 1-12. https://doi.org/10.1016/j. tate.2019.102925

Joseph, B., \& Jacob, M. (2011). Knowledge Sharing Intentions among IT Professionals in India. In S. Dua, S. Sahni, \& D. P. Goyal (Eds.), IISTM Proceedings: Information Intelligence, Systems, Technology and Management. Communications in Computer and Information Science (pp. 23-31). Springer. https://doi.org/10.1007/978-3642-19423-8_3

Kankanhalli, A., Tan, B. C. Y., \& Wei, K. K. (2005). Contributing knowledge to electronic knowledge repositories: An empirical investigation. MIS Quarterly, 29(1), 113-143. https://doi.org/ 10.230 7/25148670

Kelchtermans, G. (2006). Teacher collaboration and collegiality as workplace conditions. A review. Zeitschrift fur pädagogik, 52, 220-237.

Kelley, H. H., \& Thibaut, J. W. (1978). Interpersonal relations: A theory of interdependence. Wiley.

Khatamianfar, P., \& Ghorbani Bousari, R.(2013). Knowledge sharing in Iranian academic institution: Meta analysis approach. Procedia-Social and Behavioral Scinces, 73, 383-387. https://doi.org/10.1016/j.sbspro.2013.02.065

Kim, S., \& Ju, B. (2008). An analysis of faculty perceptions: Attitudes toward knowledge sharing and collaboration in an academic institution. Library \& Information Science Research, 30(3), 282-290. https://doi.org/10.1016/j. lisr.2008.04.003

Krejcie, R. V., \& Morgan, D. W. (1970). Determining sample size for research activities. Educational and Psychological Measurement, 30(3), 607-610. https://doi.org/10.1177/001316447003000308

Lewin, K. (1939). Patterns of aggressive behavior in experimentally created "social climates". Journal of Social Psychology, 10, 271-299. https://doi.org/10.1080/00224545.1939.9713366

Lieberman, A. (1995). Practices that support teacher development: Transforming conceptions of professional learning. Phi Delta Kappan, 76, 591-596.

Lin, H. F. (2006). Impact of organizational support on organizational intention to facilitate knowledge sharing. Knowledge Management Research and Practice, 4(1), 26-35. https://doi.org/10.1057/ palgrave.kmrp.8500083

Loebbecke, C., Van Fenema, P. C., \& Powell, P. (2016). Managing inter-organizational knowledge sharing. The Journal of Strategic Information Systems, 25(1), 4-14. https://doi.org/10.1016/j. jsis.2015. 12.002

Mawhinney, L. (2010). Let's lunch and learn: Professional knowledge sharing in teachers' lounges and other congregational spaces. Teaching and Teacher Education, 26(4), 972-978. https://doi.org/10.1016/j. tate.2009.10.039

Mann, S., Walsh, S. (2017). Reflective practice in English language teaching research-based principles and practices. Routledge.

Meredith, C., Moolenaar, N.M., Struyve, C., Vandecandelaere, M., Gielen, S., \& Kyndt, E. (2017). The measurement of collaborative culture in secondary schools: An informal subgroup approach. Frontline Learning Research, 5(2), 24-35. https://doi.org/10.14786/flr.v5i2.283

Mooghali, A. (2012). The impact of collaborative work climate on knowledge sharing intention. African Journal of Business Management, 6(19), 6114-6116. https://doi.org/10.5897/AJ BM11.2862 
Nazem, F., Mozaiini, M., \& Seifi, A. (2014). A structural equation model of knowledge management based on organizational climate in Universities. International Journal of Industrial and Manufacturing Engineering 8(2), 447-451.

Nemati-Anaraki, L., \& Nooshinfard, F. (2014). Effective organizational factors in knowledge sharing from the viewpoint of faculty members. Journal of Health Administration, 17(56), 65-79.

Newmann, F .M., King, M. B., \& Youngs, P. (2000). Professional development that addresses school capacity: Lessons from urban elementary schools. American Journal of Education, 108(4), 259-99. https://doi. org/10.1086/444249

Nezakatgoo, B., \& Behzadpoor, F. (2017). Challenges in teaching ESP at medical universities of Iran from ESP stakeholders' perspectives. Iranian Journal of Applied Language Studies, 9(2), 59-82. https://doi.org/10.22111/ IJALS.2017.3544

Ng, P. T., \& Tan. C. (2009). Community of practice for teachers: Sense making or critical reflective learning?. Reflective Practice, 10(1), 37-44. https://doi.org/10.1080/14623940802652730

North, K., \& Babakhanlou, R. (2016). Knowledge management tools for SMES. In K. North, G. Varvakis (Eds.),, Competitive strategies for small and medium enterprises (pp. 211-222). Springer. https://doi.org/10.1007/9783-319-27303-7_14

O’Dell, C., \& Hubert, C. (2011). The new edge in knowledge: How knowledge management is changing the way we do business. Wiley.

Pezeshkirad, G. H., Alizadeh, N., \& Zamani Miandashti, N. (2010). An investigation of factors influencing attitude of personnel of the agricultural extension and education organization in the ministry of Jihad-e agriculture towards knowledge sharing. Iranian Journal of Agricultural Economic and Development Research, 41-2(1), 41-50.

Phung, V. D., Hawryszkiewycz, I., \& Binsawad, M. H. (2016). Classifying knowledge-sharing barriers by organisational structure in order to find ways to remove these barriers. In Proceedings of the 8th International Conference on Knowledge and Systems Engineering (pp. 73-78). KSE. https://doi.org/10.1109/KSE.2016.7758032

Rahmatinia, K. H., \& Maleki, M. (2013). The relationship between knowledge management and organizational climate in higher education institutions. Journal of Modern Thought in Education, 8(3), 57-66.

Rajprasit,K.,Pratoomrat,P., \& Wang,T.(2015). Perceptions and problems of English language and communication abilities: A final check on Thai Engineering undergraduate. English Language Teaching, 8(3), 111-20. https:// doi.org/10.5539/elt.v8n3p111

Ramazanzade, K., Ayati, M., Shokohifard, H., \& Abedi, F. (2019). Pedagogical knowledge management and its application in medical education: A research synthesis study. Future of Medical Education Journal, 9(1), 5158. https://doi.org/10.22038/FMEJ.2019.35799.1233

Richards, J. C., \& Farrell, T. S. C. (2005). Professional development for language teachers: Strategies for teacher learning. Cambridge University Press.

Robbins, P., \& Alvy, H. B. (2003). The principal's companion: Strategies and hints to make the job easier. Corwin.

Rowley, J. (2002). Eight questions for customer knowledge management in e-business. Journal of Knowledge Management, 6(5), 500-511. https://doi.org/10.1108/13673270210450441

Sveiby, K.E., \& Simons, R. (2002). Collaborative climate and effectiveness of knowledge work-an empirical study. Journal of Knowledge Management, 6(5), 420-433. https://doi.org/10.1108/13673270210450388

Stoddart, L. (2001). Managing intranets to encourage knowledge sharing: Opportunities and constraints. Online Information Review, 25(1), 19-28. https://doi.org/10.1108/1468452011036 6661

Stoll, L., Bolam, R., McMahon, A., Wallace, M., \& Thomas, S. (2006). Professional learning communities: A review of the literature. Journal of Educational Change, 7, 221-258. https://doi.org/10.1007/s10833-006-0001-8

Tan, C. N. (2016. Enhancing knowledge sharing and research collaboration among academics: The role of knowledge management. Higher Education, 71, 525-556. https://doi.org/10.1007/s1073 4-015-9922-6

Tierney, W. G. (1988). Organizational culture in higher education: Defining the essentials. The Journal of Higher Education, 95(1), 2-21. https://doi.org/10.2307/1981868

Trehan, A., \& Kushwaha, P. (2012). The implementation of knowledge management system in B-schools.. International Journal of Multidisciplinary Management Studies, 2(2), 252-260.

Vangrieken, K., Dochy, F., Raes, E., \& Kyndt, E. (2015). Teacher collaboration: A systematic review. Educational Research Review, 15, 17-40. https://doi.org/10.1016/j.edurev.2015.04.002

Von Krogh, G. (1998). Care in knowledge creation. California Management Review, 40(3), 133-153. https://doi. org/10.2307/41165947

Van Gyn, G. H. (1996). Reflective practice: The needs of professions and the promise of cooperative education. The Journal of Cooperative Education, 31(2), 103-131. 
Wangpipatwong, S. (2009, December 4). Factors influencing knowledge sharing among university students [Conference presentation]. 17th International Conference on Computers in Education, Asia-Pacific Society for Computers in Education, Hong Kong, China.

Xue, Y., Bradley, J., \& Liang, H. (2011). Team climate, empowering leadership, and knowledge sharing. Journal of Knowledge Management, 15(2), 299-312. https://doi.org/10.1108/136732 7111119709

Yukl, G. A. (2013). Leadership in organizations. Pearson Education.

Zeinabadi, H. (2020). Breaking down the walls of weak knowledge-sharing among Iranian teachers: Investigating a less-considered leadership role of principals. Educational Management Administration \& Leadership, pp. 1-12. https://doi.org /10.1177/1741143220968160 